\title{
Possible relationships between SLA and porcine reproduction
}

\author{
C. Renard and M. Vaiman
}

INRA-CEA, IPSN-DPS-SPE, Laboratoire de radiobiologie appliquée, 178350 Jouy-en-Josas, France

(3rd Franco-Czechoslovak Meeting, INRA, Jouy-en-Josas, 13-14 December 1988)

Summary - The possible influence of the pig major histocompatibility complex on reproductive traits is reviewed. Among the parameters investigated, significant associations were observed between SLA and genital tract development in males. Several SLA haplotypes affected either positively or negatively the development of testes, the epididymes and the Cowper's glands, whereas the influence of these haplotypes on androsterone tissue content was limited. The impact of the SLA complex on female reproductive performance has been more difficult to ascertain, although some results suggest that the SLA region may interfere with ovulation rates.

The influence on prolificacy of SLA sharing between sires and dams was also investigated. Even if fertilization rate is not affected, embryonic mortality and preimplantation embryo development might be influenced by the pig MHC region. Although the litter size was not only marginally affected by the SLA complex, there is one case where SLA identity between the boar and several related sows led to significantly reduced litter size. In these families piglets homozygous for a particular SLA haplotype were almost absent, suggesting the existence of a recessive lethal gene linked to SLA.

\section{histocompatibility - reproductive traits — pigs}

Résumé - Possibilité d'associations entre SLA et la reproduction porcine. L'étude d'une éventuelle influence du système majeur d'histocompatibilité du porc (SLA) sur les performances de reproduction a été effectuée sur plusieurs troupeaux expérimentaux de I'INRA. Parmi les différents paramètres étudiés, le système SLA et le développement pondéral de plusieurs glandes du tractus génital mâle sont significativement liés. De grandes différences de développement des testicules, des glandes de Cowper et de l'épididyme sont associées à la présence d'allèles SLA particuliers chez les verrats.L'influence des allèles SLA sur le développement du tractus génital femelle est négligeable sauf sur le taux d'ovulation.

La deuxième partie de l'étude décrit les effets de l'identité des caractères SLA chez géniteurs à différentes étapes de la gestation. Deux types de croisements sont comparés : dans le premier type, le verrat et la truie possèdent un des caractères SLA identiques et dans le second, le verrat et la truie sont totalement différents. Le taux de fécondation ne varie pas selon le type de croisement. La taille de portée semble peu affectée par le complexe SLA sauf dans un cas ou l'identité d'un haplotype SLA entre le verrat et la truie entraîne une réduction significative de la taille de portée à la naissance. Dans ces familles, les porcelets homozygotes pour le système génétique SLA sont en proportion très significativement inférieure aux $25 \%$ attendus. De plus, à la fin du premier tiers de la gestation, la mortalité et le développement embryonnaire semblent affectés par ce type de croisement. Ces observations sont reproductibles sur plusieurs générations. Ceci suggère l'existence de gènes récessifs létaux ou de gènes impliqués dans la vitesse de développement des embryons, localisés à proximité du complexe génétique SLA.

histocompatibilité - caractères de la reproduction - porc 


\section{INTRODUCTION}

Successful reproduction in the pig depends on many different coordinated processes, among which the production of gametes, the fertilization rate and the survival rate of conceptuses are of particular importance. These parameters are clearly under the control of a number of genes which are probably scattered throughout the whole genome. Most likely these genes have balanced effects, which may explain the observed low heritability of litter size. Many attempts have been made to improve pig prolificacy by selection programmes (Legault, 1985; Le Roy et al., 1987) and marker genes are eagerly needed for such purpose. Therefore, the MHC seems a good candidate because the MHC region has been shown to be involved in reproduction traits in different species (Gill, 1986). For example, in mice the $\mathrm{MHC}$ region harbours the Ped gene which controls embryonic development rate before implantation (Brownell \& Warner, 1988). In the rat the MHC also plays a prominent role in fetal life (Kunz et al., 1980) and in the human the MHC influences the levels of steroid hormones (White et al., 1986).

As the MHC plays a crucial role in selfrecognition, an immune reaction of the mother against the fetuses, which are semi-compatible allografts, is often noted. The MHC antigenic specificities are particularly frequent targets of the reaction, but without harmful consequences on litters.

Studies on the pig MHC (known as swine leukocyte antigens or SLA), by ourselves and other laboratories have demonstrated that the SLA region is homologous to the MHC region in other species (Vaiman, 1988). In all species studied, the MHC complex comprises three classes of genes, among which class I and class II are highly polymorphic, leading to the existence of numerous distinct combinations of alleles or haplotypes.

The relationship between SLA and reproductive performances has been systematically studied in all INRA herds under reproductive selection trials during the last 10 years (Renard et al., 1985; Renard, 1987). These studies were carried out in collaboration with other laboratories involved in studies of quantitative genetics and reproductive physiology. Relevant observations collected during that period are presented in this report.

\section{MALE GENITAL DEVELOPMENT AND SLA}

SLA typing was performed on boars from an INRA experimental herd evaluated for the relationship between the androstenone tissue content and genital tract development. Altogether, 197 young boars, including those sired by males chosen randomly for the control group, selected for low androstenone content and either large or small testes were sampled at 104 and 115 $\mathrm{kg}$ of weight. The statistical model used to analyze the data has already been reported (Rothschild et al., 1986) and uses a complete or partial model of variance analysis including several effects and their interactions. Significant associations were found between certain SLA haplotypes and the traits measured (Table I). Thus, the boar genital tract development was influenced by different haplotypes. The results on testes weight are detailed in Figure 1 : the males bearing the SLA $\mathrm{H} 16$ or $\mathrm{H} 15$ haplotypes had larger testes, whereas those with SLA H4 and $\mathrm{H} 8$ had significantly smaller testes than the average value measured in the whole herd. 
Table I. Associations between SLA haplotypes and male tract development.

Body weight Traits measured

SLA haplotypes associated with :

high level low level

\begin{tabular}{|c|c|c|c|c|c|}
\hline \multirow[t]{2}{*}{$104 \mathrm{~kg}$} & \multicolumn{2}{|l|}{ Androstenone fat level } & \multicolumn{2}{|l|}{$\mathrm{H} 2^{*}$} & $\mathrm{H} 10^{*}$ \\
\hline & $\begin{array}{l}\text { Testes area } \\
\text { Testes width }\end{array}$ & $\mathrm{H} 16^{*}$ & $\begin{array}{l}\mathrm{H} 15^{*} \mathrm{H}^{+} \\
\mathrm{H} 15^{\circ} \mathrm{H}^{*}\end{array}$ & $\begin{array}{l}\mathrm{H} 8^{* *} \\
\mathrm{H} 8^{* *}\end{array}$ & $\begin{array}{l}\mathrm{H} 4^{*} \mathrm{H}^{+} \\
\mathrm{H} 4^{*} \mathrm{H}^{+}\end{array}$ \\
\hline \multirow[t]{2}{*}{$124 \mathrm{~kg}$} & Androsterone fat level & & NS & & NS \\
\hline & $\begin{array}{l}\text { Testes weight } \\
\text { Epididyme weight } \\
\text { Cowper's gland weight } \\
\text { Cowper's gland length }\end{array}$ & $\begin{array}{l}\mathrm{H} 16^{* *} \\
\mathrm{H} 16^{* *} \\
\mathrm{H} 16^{* *} \\
\mathrm{H} 16^{* *}\end{array}$ & $\begin{array}{l}\mathrm{H}_{15^{* *}} \\
\mathrm{H} 15^{* *} \mathrm{H}^{*} \\
\mathrm{H} 2^{+} \\
\mathrm{H} 2^{+}\end{array}$ & $H 8^{*}$ & $\begin{array}{l}\mathrm{H} 4^{* *} \\
\mathrm{H} 4^{*} \mathrm{H}^{+} \mathrm{H}^{+}+ \\
\mathrm{H} 4^{*} \mathrm{H} 6^{+} \mathrm{H} 1+ \\
\mathrm{H} 4^{*} 6^{*}\end{array}$ \\
\hline
\end{tabular}

$+P<0.10 ;^{*} P<0.05 ;^{*} P<0.01$.

\section{SOW REPRODUCTIVE TRAITS}

Several studies on possible associations between SLA and litter size in the three INRA herds did not produce conclusive re-

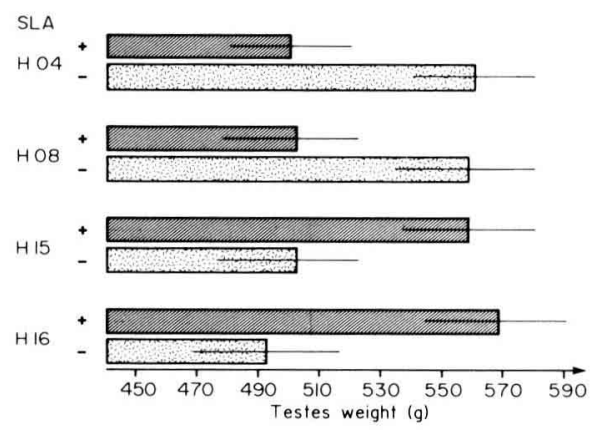

Fig. 1. Comparison between the averaged testes weight of boars with (四) or without ( $\square$ ) some SLA haplotypes (measured at $124 \mathrm{~kg}$ of body weight). sults (Renard, 1985). In contrast, it is suggested that the age of puberty, the ovulation rate and levels of sexual hormones are related to SLA. However, the experimental conditions at the times of observation were not completely satisfactory. For instance, the lack of appropriate controls casts some doubts on the results. Consequently, further studies are needed with more suitable material. Three lines of miniature pigs inbred for specific SLA haplotypes have been raised by Sachs in the United States. It appears that in these lines the SLA complex influenced both the litter size and ovulation rates. Although no correlations were found between SLA genotypes and estrone and estradiol $17 / \beta$ in blood or uterine flushing during pregnancy, a relationship between the embryonic development rate and SLA haplotypes was noted in the sows of this herd (Conley et al., 1988; Ford et al., 1988). 


\section{INFLUENCE OF SLA SHARING EFFECT ON REPRODUCTION}

In man, various reports (Reznikoff-Etievant et al., 1986) suggest that identity for HLA haplotypes between couples may lead to infertility and miscarriages. Also, a deficit of HLA homozygotes is found in human isolates where consanguinity is high. These findings prompted us to investigate the influence of SLA compatibility between boars and sows on traits like fertilization rate, embryonic mortality, embryo development and litter size. Studies were performed in a herd selected for prolificacy for 14 generations. We compared the results of matings involving sires and dams sharing at least one SLA haplotype (one third of the couples, and $25 \%$ SLA homozygous piglets expected), with those where each parent carried entirely distinct haplotypes.

\section{Fertilization failure}

Fertilization failure was measured by return to estrus. There was no significant difference in fertilization rate between the groups, although the highest failure rate was for cross-bred matings, second parity and when the boar and the sow shared one haplotype.

\section{Embryonic mortality}

The rate of embryonic mortality was measured when the sows were slaughtered, between day $30-35$ of gestation. It is at that period that the exponential growth phase of the embryos starts (Legault \& Leuillet, 1973). The viability of each individual embryo was recorded according to visual examination.
Only a limited number of haplotypes could be statistically taken into account because all other haplotypes shared by couples had frequencies too low to be analyzed. Among those retained, a significant embryonic loss was found only in matings in which one boar and a group of related sows shared the SLA H2 haplotype (Table II). The sows had all inherited the SLA H2 haplotype from the same grandfather. This effect was not observed in a second group of sows bearing an SLA H2 haplotype of another origin. The presumed identity between the SLA H2 haplotypes found in these two groups of sows and the boar, although suggested both by serology and class II molecular analyses, can be questioned, however, as many of the genes linked to SLA have not been explored. In addition, the $\mathrm{MHC}$ may merely play the role of a marker for the gene connected with our observation.

\section{Embryo development}

Embryo growth parameters were measured in 642 embryos already used for embryonic loss studies. There was a significant effect on embryonic development after 30 days, and only in matings where the boar and the sow shared SLA H2, leading to SLA $\mathrm{H}_{2}$ homozygous conceptuses (Table III). The SLA H2 haplotype involved was the same as that which negatively affected the embryo viability.

\section{Litter size}

The effect on litter size of SLA sharing between parents was evaluated in 251 families including 117 purebred Large White 
Table II. Embryonic loss in relation to SLA status at days 30-35.

\begin{tabular}{|c|c|c|c|}
\hline \multicolumn{2}{|c|}{$S L A$} & \multirow{2}{*}{$\begin{array}{l}\text { Percentage of loss } \\
C L-L E \times 100\end{array}$} & \multirow[t]{3}{*}{ No. of litters } \\
\hline \multirow[t]{2}{*}{ sire } & \multirow[t]{2}{*}{ dam } & & \\
\hline & & $C L$ & \\
\hline $2 /-$ & $2 a /-$ & $35.5 \pm 6.1$ & 17 \\
\hline $2 /-$ & $2 b /-$ & $20.4 \pm 3.3$ & 11 \\
\hline $2 /-$ & $-1-$ & $19.8 \pm 4.3$ & 16 \\
\hline $2 /-$ & $\left(\begin{array}{c}2 b /- \\
-/-\end{array}\right)$ & $19.8 \pm 2.6$ & 27 \\
\hline
\end{tabular}

Pooled results from 3 generations. 2a: SLA haplotype derived from one grandfather; $2 \mathrm{~b}:$ SLA haplotype derived from another grandfather; $\mathrm{CL}$ : corpus luteum; $\mathrm{LE}$ : live embryos; $P<0.05$.

pigs and 134 crossbred Pietrain $\times$ Large White. The results are summarized in Table IV. They unexpectedly disclosed a detrimental effect on litter size in cross-bred families when the parents shared at least one SLA haplotype but this effect did not occur in pure-bred families. The haplotypes involved were SLA $\mathrm{H} 1, \mathrm{H} 2, \mathrm{H} 4$, among which SLA H2 had the main effect.
The negative influence of SLA H2 was stricking as the same haplotype apparently procuded a strong heterosis effect in crosses between Large White sows and Pietrain boars with no SLA haplotype in common. The reduction in litter size, when the SLA H2 haplotype was involved, could be correlated to a major deficit in SLA H2 homozygous piglets at birth.

Table III. Embryonic development at 31 and 32 days of pregnancy (263 embryos).

\begin{tabular}{|c|c|c|c|c|c|}
\hline \multicolumn{2}{|c|}{ SLA mating type } & \multirow{2}{*}{$\begin{array}{c}\text { Placenta } \\
\text { weight } \\
\text { (g) }\end{array}$} & \multirow{2}{*}{$\begin{array}{l}\text { Fluid } \\
\text { vol. } \\
\text { (mi) }\end{array}$} & \multirow{2}{*}{$\begin{array}{c}\text { Embryo } \\
\text { weight } \\
(g)\end{array}$} & \multirow{2}{*}{$\begin{array}{c}\text { Embryo } \\
\text { lenght } \\
(\mathrm{mm})\end{array}$} \\
\hline Sire & $d a m$ & & & & \\
\hline $2 /-$ & $2 /-$ & 27.8 & $171 \mid$ & 1.76 & 25.9 \\
\hline $2 /-$ & $-1-$ & 43.5 & 208 & 26.9 & 29.2 \\
\hline $1 /-$ & $1 /-$ & 37.3 & 241 & 2.61 & 29.1 \\
\hline $1 /-$ & $-1-$ & 43.9 & 228 & 2.41 & 28.1 \\
\hline
\end{tabular}

$\cdot P<0.05$. At day $30, \mathrm{H} 2$ SLA mating type does not decrease the growth of embryos and placenta (150 embryos). 
Table IV. Average of litter size at birth depending on SLA mating type.

\begin{tabular}{|c|c|c|c|c|c|}
\hline & $\begin{array}{l}\text { Generation } \\
\text { Breed } \\
\text { Parity }\end{array}$ & & $\underset{1}{L W \times L W}$ & 14 & $\begin{array}{c}L W \times P \\
2\end{array}$ \\
\hline $\begin{array}{c}\text { SLA mating type } \\
\text { A }-x= \\
A-x-1-\end{array}$ & & $\begin{array}{r}n \\
27 \\
45\end{array}$ & $\begin{array}{c}M \\
10.1 \pm 0.6 \\
11.5 \pm 0.5\end{array}$ & $\begin{array}{l}n \\
26 \\
63\end{array}$ & $\begin{array}{c}M \\
9.6 \pm 0.6 \\
11.7 \pm 0.4\end{array}$ \\
\hline & $\begin{array}{c}\text { Generation } \\
\text { Breed } \\
\text { Parity }\end{array}$ & & $\begin{array}{c}L W \times L W \\
1\end{array}$ & 15 & $\begin{array}{c}L W_{x} P \\
2\end{array}$ \\
\hline $\begin{array}{l}\text { SLA mating type } \\
A-\times A- \\
A-x-1-\end{array}$ & & $\begin{array}{r}n \\
19 \\
26\end{array}$ & $\begin{array}{c}M \\
10.4 \pm 0.7 \\
10.2 \pm 0.6\end{array}$ & $\begin{array}{r}n \\
14 \\
31\end{array}$ & $\begin{array}{c}M \\
9.9 \pm 0.8 \\
12.3 \pm 0.5\end{array}$ \\
\hline
\end{tabular}

$n$ : No. of litters; $M$ : average litter size; $P<0.05 ; \mathrm{LW}:$ Large White breed (boars and sows); $P$ : Pietrain breed (boars).

\section{DISCUSSION AND CONCLUSION}

The pig MHC complex is composed of functionally distinct families of genes. The majority of these genes controls the immune response against all the $T$-cell dependent antigens including the $\mathrm{MHC}$ alloantigen products. Therefore an immune reaction towards paternal incompatible specificities during gestation can be expected. In mice, matings between nonhistocompatible males and females may eventually lead to higher placenta weights and higher litter sizes than in compatible matings (Beer \& Billingham, 1977). We have found in pig that SLA sharing between boars and sows could depending on the haplotype, result in a deficit of homozygous piglets. For the haplotype SLA H2, it was accompanied by a drastic reduction in litter size, at least in one related group of sows. The reduction was apparently linked to a high mortality rate before day 35 of gestation.

No clear explanation can be proposed for our observations. In miniature pigs, preliminary results suggest the existence of a Ped-like gene linked to SLA (Ford et al., 1988). As a marked variation in development rate is considered detrimental to the less developed embryos of the same litter, the existence of a Ped gene in SLA might play some role in intrauterine embryo competition.

The various associations seen between SLA and reproductive traits by ourselves and others depend most certainly on various phenomena involving different genes located within but also outside the SLA region. The role of recessive lethal genes in linkage desequilibrium with SLA should be considered. Similarly, SLA haplotype pref- 
erential transmission (Philipsen \& Kristensen, 1985) seen in the progeny of some boars is reminiscent of the $\mathrm{H}-2$ segregation distortion in the mouse, where the phenomenon is linked to the T-complex which is in the neighbourhood of $\mathrm{H}-2$ (Klein et al., 1987). In conclusion, it appears that certain SLA haplotypes have an effect on pig reproduction. In order to verify this result and to further understand the mechanisms involved there is a need to take into account the SLA complex as well as other genes already known to have some influence on reproduction. These genes include the transferrin gene (Kristjanson, 1964), the $H$ (Rasmunsen \& Hagen, 1973) and the $E$ blood group systems (Linklater et al., 1973) and also the $C$ and $J$ systems (Jensen et al., 1968) which are in the same region as the SLA.

\section{ACKNOWLEDGMENTS}

We are mosi grateful to G. Bolet and J.-P. Bidanel for the statistical work and to $P$. Rombauts for his collaboration with the physiological observations. The excellent technical assistance of $P$. Dando, N. Bourgeaux and J.-J. Leplat is also acknowledged.

\section{REFERENCES}

Beer A.E. \& Billingham R.E. (1977) Histocompatibility gene polymorphisms and maternalfetal interaction. Transplant. Proc. 9, 1357-1401

Brownell M.S. \& Warner C.M.(1988) Ped gene expression by embryos cultured in vitro. Biol. Reprod. 39, 806-811

Conley A.J., Jung Y.C., Schwartz N.K., Warner C.M., Rothschild M.F. \& Ford S.P. (1988) Influence of SLA haplotype on ovulation rate and litter size in miniature pigs. J. Reprod. Fertil. 82, 595-601
Ford S.P., Schwartz N.K., Rothschild M.F., Conley A.J. \& Warner C.M. (1988) Influence of SLA haplotype on preimplantation embryonic cell number in miniature pigs. J. Reprod. Fertil. 84, 99-104

Gill T. (1986) Immunological and genetic factors influencing pregnancy and development. Am. J. Reprod. Immunol. Microbiol. 3, 116-120

Jensen E.L., Smith C., Baker I.N. \& Cox D.F. (1968) Quantitative studies on blood group and serum protein systems in pigs : 11. Effects on production and reproduction. J. Anim. Sci. 27, 857-862

Klein J., Vincek V., Kasahara M. \& Figueroa F. (1987) is there a $t$ complex in man ? Proc. 18th Study Group, R.Coll. Obstetricians (R.W. Beard \& F. Sharp, eds.), R. Coll. Obstet. Gynaec., London, pp. 269-274

Kristjanson F.K. (1964) Transferrin types and reproductive performance in the pig. $J$. Reprod. Fertil. 8, 311-317

Kunz H.W., Dixon B.D., Taylor F.H. \& Greiner D.L. (1980) Growth and reproduction complex in the rat. Genes linked to the major histocompatibility complex affect development. J. Exp. Med. $152,1506-1518$

Legault C. (1985) Selection of breeds, strains and individual pigs for prolificacy. $J$. Reprod. Fertil. (suppl. ) 33, 151-166

Legault C. \& Leuillet M. (1973) Etude de quelques facteurs de variation du poids de l'embryon et du placenta chez la truie primipare au trentième jour de la gestation. Ann. Biol. Anim. Biochim. Biophys. 13, 25-36

Le Roy P., Legault C., Gruand J. \& Ollivier L. (1987) Heritabilité réalisée pour la taille de portée dans la selection de truies dites hyperprolifiques. Genet. Sel. Evol. 19, 351-364

Linklater K.A., McTaggart \& Imlah T. (1973) Haemolytic disease of the newborn, thrombocytopenic purpurea and neutropenia occurring concurrently in a litter of piglets. Br. Vet. J. 129, 36-40

Philipsen M. \& Kristensen B. (1985) Preliminary evidence of segregation distorsion in the SLA system. Anim. Blood Groups Biochem. Genet. $16,125-133$

Rasmunsen B.A. \& Hagen K.L. (1973) The H blood group system and the reproduction in pig. J. Anim. Sci. 37, 568-573 
Renard C., Bolet G., Dando P. \& Vaiman M. (1985) Relations d'un marqueur génétique, le complexe majeur d'histocompatibilité, avec la prolificité des truies et la mortalité des porcelets. Journées de la Recherche Porcine en France (Institut Technique du Porc, Paris, ed.) 17, 105112 (English abstr. Ann. Zootech. 34, 364-365)

Renard C. (1987) Effect of feto-maternal major histocompatibility differences on litter size in pigs. Proc. 18th Study Group, R.Coll. Obstetricians (R.W. Beard \& F. Sharp, eds.), R. Coll. Obstet. Gynaec., London, pp. 105-118

Reznikoff-Etievant M.F., Durieux I., Lobet R., Dambrioso A., Toure C., Dufraisse C., Mateos M.C., Castellano F., Muller J.Y. \& Huchet J. (1986) La maladie abortive immunologique et son traitement par immunothérapie. Rev. Fr. Transfus. 29, 135-148

Rothschild M.F., Renard C., Sellier P., Bonneau M. \& Vaiman M. (1986) Swine lymphocyte antigen (SLA) haplotype effects on male genital tract development and androstenone level. 3rd World Congress on Genetics Applied to Livestock Production. (G.E. Dickerson \& R.K. Johnson, eds), Lincoln, Nebraska, USA, vol. II, pp. 197-202

Vaiman M. (1988) Histocompatibility systems in pigs. Prog. Vet. Microbiol. Immun. 4, 108-133

White P.C., Werkmeister J., New M.I. \& Dupont B.O.(1986) Steroid 21-hydroxylase deficiency and the major histocompatibility complex. Human Immunol. 15, 404-415 